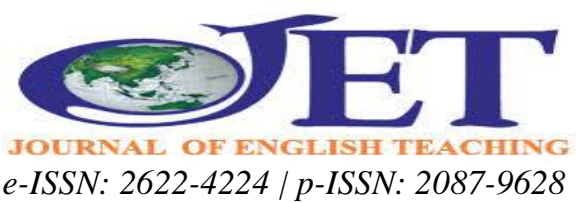

\title{
Students' Perception of Digital Texts Reading: A Case Study at the English Education Department of Universitas Kristen Indonesia
}

\author{
Benny Hinn Manalu \\ Bennyhinn271@gmail.com \\ English Education Department, Faculty of Teacher Training and Education, \\ Universitas Kristen Indonesia, Indonesia
}

DOI: http://dx.doi.org/10.33541/jet.v5i3.1312

\begin{abstract}
This study was conducted to explore students' perceptions of reading digital texts. To attain the objective, the data were collected through an online questionnaire uploaded in Google Form and an interview. The questionnaire was intended to collect quantitative data concerning the participants' responses about their interest and motivation, digital text reading efficacy, problems in digital text reading, and preference towards digital or printed text reading. The participants of the study were 65 English pre-service teachers selected from the whole students of the English Education Department of Universitas Kristen Indonesia in the academic year 2019/2020, and the sample was 65 participants. The collected data were analyzed descriptively using Microsoft excel. The findings revealed that the participants perceived digital texts reading positively. They preferred reading digital texts because they were motivating, interesting, and suite their expected way of reading. The main problem they encountered in reading digital texts was due to the screen light which could irritate their eyes.
\end{abstract}

Keywords: digital text, printed texts, student's perception

\section{INTRODUCTION}

At the present day, technological advancement keeps on causing accelerative changes in almost every way of life, including education Science (2018) stated, "Technology has transformed the way we do things and the way we live". Reading is no exception to it. Technology makes information easy to access, especially in digital sources. By connecting to the internet, people have many optional tools to access information, such as WhatsApp group, online news, Wikipedia, journals, etc. Digital texts provide a new format of text in terms of view, font, and color to readers to interact with. Digital texts have essentially offered readers a new experience in reading.

One of the consequences of digital text availability is that today the way students read has changed. Many students now tend to read the digital texts which give them a new experience. The digital texts also advance reading experience because they offer a huge variety of information. Giebelhausen (as cited in Pardede 2019b) accentuated "The use of digital tools as reading devices has also driven educational institutions to move to 
paperless classrooms around the world." At the English Education Department of Universitas Kristen Indonesia, some of the lecturers have provided students with many digital sources, with which they can get more knowledge without having to afford the printed texts. However, some other lecturers just use traditional printed texts. Students. Therefore should deal with both reading modes.

Both digital and print readings can help the readers improve their comprehension reading skills which are crucial in the educational success of the students. Baier (2005) pointed out reading comprehension is an important skill needed in all areas of the subject. Additionally, Pardede (2017) accentuated that reading is the most vital skill every EFL learner should master due to several reasons. First, EFL learners study English in an environment where English is not the primary language of the society. Their lack of inputs from their daily interactions could be overcome best through reading. Secondly, numerous studies have shown the important contribution of reading to one's personal and intellectual development, further studies, job success, and career development. Third, reading skills increase a learner's mastery of other language learning areas (Anderson, 2003). Reading provides the learners with various good sentence structures so many times that they become accustomed to them. It also develops the learners' vocabulary by letting them get the most frequently used and useful words and learn them in context. Finally, reading advances writing skills for it allows the learners to figure out how to express ideas through words, how to use punctuation correctly, and so on. Elley (1991) stated there was a "spread of effect from reading competence to other language skills - writing, speaking and control over syntax" (p. 404).

However, the results of studies comparing the effect of reading digital texts versus printed texts to reading comprehension showed inconsistent results. Some studies showed printed reading supremacy, some others indicated no significant difference between the two formats to comprehension, while some others revealed digital reading prevailed printed text reading (Pardede, 2017). Despite that inconsistency, Pardede (2017) argued that due to technological ubiquity in all life sectors, digital texts literacy is unavoidable. Thus, to use them as a complementary or a substitute for resources teachers have already had is the best choice.

In every educational activity, students' perception is one of the most important factors that determines the activity effectiveness. The more positive the students' perception, the more conducive the activity will be, and the better results will be achieved. Based on the author's informal observation and experience, the students of the English Education Department of UKI had different opinions concerning reading digital and printed texts. Some faculties have provided various digital modules and journals. Some of the classes have also employed blended learning requiring the students to use digital files. Some of the students just use the digital files, but some others print them so that they could put notes, underline and mark the printed texts to help them comprehend it.

This study aimed to explore students' perception of reading digital or printed texts at the English Education Department of UKI. To be more specific, this study aimed at describing the students' perception of reading comprehension using digital and printed texts in their academic life. The research question is formulated as follows: "What is students' perception of using digital and printed texts in their academic life?" 


\section{LITERATURE REVIEW}

\section{Effect of Technological Advancement to Reading}

No one can imagine how learning can take place without texts (modules, textbooks, articles, handouts, etc.) In conventional learning, texts are one of the major sources of information, guides and instructions for learning. In foreign language learning, in particular, texts are one of the major language input. Different from children who receive massive extensive input from their surrounding environment while learning their mother tongue, foreign language learners need to maximize texts as one of the major language input. They provide materials for developing receptive skills and offer activities, such as discussion and role-play, to promote productive skills.

Technological advancement, however, has increased the use of online information. Many academic activities have been using the internet to get digital sources for getting information, and this has caused fundamental changes in the use of texts. Most learning institutions have increasingly adopted digital texts as a medium of teaching and learning (Wu \& Chen, 2018). Digital text explosion has also found its way into many classroom activities, including in EFL learning. Digital texts are now used to facilitate online learning and blended learning. Even the traditional face-to-face learning classes have also employed digital texts.

Unlike printed texts, digital texts have a different view, color, feature, font, etc., which makes the readers more interested in reading digital texts. What is more, digital texts also offer flexibility and convenience because they can be accessed anytime and anywhere by using smartphones or tablets. These features make digital texts very potential to motivate students to learn independently, without waiting for their lecturers to give them materials.

\section{Printed Text}

Printed texts refer to the conventional reading materials provided in the forms of textbooks, newspapers, books, magazines, handouts, and so on. Printed texts are tangible objects having a beginning and an end. It is also hierarchical, intended for private reading, and provides a very linear and static reading experience to the reader (Pardede, 2019). Readers certainly can control their experience in reading printed text, i.e. by flipping through the pages to rearrange what they read. However, printed text is "designed to be read in a linear fashion" and its "features are not malleable" (Coiro, 2003, p.4).

A printed text can practically be read in two ways: linear or deep reading and scanning. Deep reading is conducted by linearly looking at the written symbols starting from the page's top left-hand corner and vertically descending to the bottom and end at the right-hand corner while involving concentration and emotional engagement while interacting with the text to interpret the author's messages. Since the information is presented in sections, to avoid missing its parts, the reader should follow the logical relationship of the text sections while he moves from paragraph to paragraph and from one page to another. The fact that the text is linear and static enables the reader to pause for paying more attention to specific parts or re-read certain parts. This assists him to grasp the author's ideas.

Scanning is conducted for reading some printed texts (e.g. dictionaries and encyclopedia) which aim to let the reader skip from page to page for locating specific information. 


\section{Digital Texts}

Since a digital text is made available in digital devices that continuously evolve, the definitions of digital texts also evolve. Therefore, there is no single definition that researchers consensually agree with (Nelson, 2008; Liaw \& Huang, 2014). Some researchers (Nelson, 2008; Liaw \& Huang, 2014) defined a digital text as the digital version of printed texts read on a digital device (e.g., a smartphone, computer, tablet or device specifically designed for reading e-texts. Other researchers (e.g. Baki, 2010) described it as a text designed to be read over technology devices, which, unlike printed texts, offers some extra features that allow readers to interact with the text by using sound, visuals, and links. Still others (e.g. Vassiliou \& Rowley, 2008) view it as a digital format created with an abundance of new features such as search and crossreference functions, multimedia features and hypertext links. Despite all the differences in the definitions, they agree that a digital text involves technological tools to view and read books.

Digital texts can be the ones kept in digital devices or those accessed from the internet in the form of a web page, text message, or online postings (e.g. blogs). Since digital texts are electronically generated and multimodal (combining texts with audio, video, image, and hypertext), they become more interactive than a printed text and offer the readers to explore in a nonlinear way. Moreover, contrasting to the printed text which is static, digital texts are not in a constant state. Their shape, size, location, and web text color can be changed. Such features can make digital texts advantageous, for a reader can, for example, can adjust the font size to his need. However, the font size increase will limit the amount of text visible to the reader so that it is more difficult to relate the information presented in one section to those in other sections. This will reduce the reader's ability to follow the logical connection between ideas.

Relating the digital and printed text features to the reading strategies required to accommodate them, four major differences between printed and digital are identified. First, print texts are usually linear, but digital texts are often non-linear or multi-linear (Chen, 2009). Next, unlike printed texts which are usually characterized by a prefixed and predictable path, the path of digital texts takes a random and unpredictable manner. The third, due to the limitation of the computer screen space (through which the reader looks at the text), less text can be seen at one time in the digital text. Thus, compared to printed text readers, digital readers face more challenges in their attempt to comprehend what they are reading (Coiro, 2003). Finally, hyperlinks availability in digital texts makes them more complex for readers to navigate, both in their mind and physically on the screen (Coiro \& Dobler, 2007).

\section{Students' Use of Digital Texts}

Although digital texts are relatively new and keep on developing, they have been increasingly adopted as a medium of teaching and learning (Wu \& Chen, 2018). Statistics show that the unit sales of the e-book (one of the most popular types of digital texts) were almost 200\% up in 2009 compared to 2008 (Shumaker, 2017) Inferring from a five year (2005 to 2009) market trend, Shumaker (2017) indicated that the e-book market continued to grow. The survey carried out by an educational technology company, VitalSource Technologies, in 2015 exposed that $78 \%$ of students regularly read digital course materials, increased from $48 \%$ gained in the survey conducted in 2011 . 
Current researches indicate that the continuous growth of digital texts among students is due to some advantages offered by digital texts. First, digital books are generally cost-effective for students (Johnson et al., 2010; Maher, 2010). Shepperd (2008) reported e-text cost 50-60\% less than printed texts. This should also appeal to students who have been aware of the noteworthy increases in textbook prices during their short term at the academy. Second, digital texts offer convenience for storing digital texts that enable institutions to avoid using so much physical space (Pattuelli \& Rabina, 2010), and digital texts are convenient to carry anywhere so that readers do not need to worry about their heavyweight (Kiriakova et al., 2010). Third, digital texts are so accessible that students and teachers can easily access them online at any time and wherever (Doering, Pereira \& Kuechler, 2012). Fourth, digital texts can be searched easily, and this supports students and teachers in their learning and teaching (Abram, 2010). Fifth, e-books are user-friendly, can be annotated, copy and paste text, and for some users, they are easier to read (Doering, Pereira \& Kuechler, 2012).

Despite the many advantages offered by digital texts, several studies, however, revealed that some people still preferred printed than digital texts. Pechenkinab, Rossa, Carol, and Aeschlimanb (2017) reported that printed texts contributed more to increased comprehension and recall than e-texts. They revealed that reading printed texts help the readers to recall more words than reading digital text. Mizrachi (2014) reported that some students preferred printed texts for longer readings, especially if it is more than ten pages long. But for shorter texts, their behaviors vary.

\section{Students' Perception of Digital Texts}

Based on Bloom's Theory of Mastery Learning, Kazu, Kazu, \& Ozdemir (2005) posited that providing learners the opportunity to choose and use learning tools that meet their preferences and learning styles can facilitate successful learning. Besides, every aspect of learning is affected by the students' perception. Therefore, to optimize the use of digital texts in learning necessitates, students' perception needs to be considered. Baker-Eveleth (as cited in Pardede, 2007) claimed that their perception affects students and teachers to use or reject digital texts. Sun et al. (2012) reported that students' perceptions $\mathrm{n}$ how helpful e-books are for facilitating their learning have a direct to their learning outcomes. That is to say, a student's learning outcomes will enhance if he thinks that an e-book is helpful. It was also found that the students' learning outcomes are also affected by their perception of the use of e-books in class.

Additionally, Shiratuddin and Landoni (2003) reported that the possibility to use devices, e-books, and e-book builder without much effort makes students very satisfied using digital texts. Shelburne's (2009) study pointed out that undergraduate students, compared to faculty, tend to perceive digital texts positively because of the availability of many sources that help them to get information. Another study reported that around $90 \%$ of e-book users in an Indian academic environment were very satisfied and somewhat satisfied with their use of e-books, and, compared to faculty, students tend to use e-books more often (Anuradha \&Usha, 2006)

Various studies have also shown that although students have a strong preference for using printed books (Jamali et al., 2009; Paxhia, 2011; Perry, 2005; Shelburne, 2009), academic libraries providing access to e-books reported the use rate of their ebook collection was equal to or greater than that of their printed book collection (Bailey, 2006; Rose \& Li, 2007). Other studies (Levin Clark, 2006; Nicholas \& Lewis, 2008) showed that students were willing to ds e-books with a limited amount of text. In other 
words, students preferred printed texts to read long texts. In contrast, Koçak, et al (2016) found that students preferred e-books while studying. Khan, et al. (2016) and Lewellen, et al. (2016) noticed that postgraduate students used e-books more than the undergraduates. Carroll, et al (2016) found that digital texts were favored than printed texts for general reference books. Kumbhar (2018) believed that the participants' national background must e attribute these varied results.

\section{METHOD}

This study employed a mixed-methods design, which is defined by Creswell and Clark (as cited in Pardede, 2019) as "a procedure for collecting, analyzing, and mixing both quantitative and qualitative methods in a single study or a series of studies to understand a research problem". The mixed-methods type used in this study is an explanatory sequential mixed methods design because it commenced with quantitative data collection and proceeded with qualitative data collection intended to elaborate the previously obtained quantitative results. The quantitative data was collected using an online questionnaire posted in google form, while the qualitative data was obtained through a focus semi-structured open-ended interview.

The population in this study was the whole students of the English Education Department of Universitas Kristen Indonesia who attended classes in the academic year in 2019/2020. The sample was 65 students selected using the cluster sampling technique. This study was conducted in June 2019.

The questionnaire employed in this study was adapted from Demirici (2007). Some modifications were made to address the research question. It consists of 16 statements about reading using digital or printed reading texts covering four dimensions: motivation and interest in reading digital texts, digital texts reading efficacy, difficulty in digital texts reading, and preference for reading digital or print texts. The statements were responded by the participants by selecting one out of the four options: 4 (strongly agree), 3 (agree), 2 (disagree), and 1 (strongly disagree). To examine the questionnaire's reliability, it was tested using Cronbach's Alpha Test. The overall Cronbach Alpha Coefficient of the questionnaire is $(r=.85)$, which indicates a high degree of internal consistency. The focus semi-structured open-ended interview was conducted to validate the data collected by using the questionnaire. It was carried out to understand the respondents' point of view, not to make a generalization.

The quantitative data obtained through the questionnaire were analyzed using descriptive analysis technique. The data obtained through the focused semi-structured open-ended interview was used to support the quantitative data.

\section{FINDINGS AND DISCUSSION}

\section{Motivation and Interest in Reading Digital Texts}

As shown in Table 1, the participants were more interested to read digital text than reading printed texts. Only $23.1 \%$ of them "strongly disagreed" and "disagreed" to the statement that it is more interesting to read digital text than reading printed texts. More than three-fourth $(76.9 \%)$ "agreed" and "strongly agreed" with the statement. The majority of them found reading digital texts motivating, exiting, more comfortable and emerged positive experience that they would often use digital texts in learning. This finding clarified Gilbert's (2017) finding that students' motivation to read digital text is higher than printed texts. 
Table 1

Motivation and Interest in Reading Digital Texts $(N=65)$

\begin{tabular}{llccccc}
\hline No & \multicolumn{1}{c}{ Statements } & SD & D & A & SA & M \\
\hline 1 & Reading digital texts is motivating & $2(3.1)$ & $\begin{array}{c}22 \\
(33.8)\end{array}$ & $\begin{array}{c}37 \\
(56.9)\end{array}$ & $4(6.2)$ & 2.66 \\
\hline 2 & More interested to read digital than printed texts & $3(4.6)$ & $\begin{array}{c}12 \\
(18.5)\end{array}$ & $\begin{array}{c}45 \\
(69.2)\end{array}$ & $5(7.7)$ & 2.8 \\
\hline 3 & $\begin{array}{l}\text { feel comfortable when studying or reading using digital } \\
\text { texts }\end{array}$ & $5(7.7)$ & $\begin{array}{c}25 \\
(38.5)\end{array}$ & $\begin{array}{c}33 \\
(50.8)\end{array}$ & $2(3.1)$ & 2.49 \\
\hline 4 & The features of digital texts make them exiting to read & $2(3.1)$ & $\begin{array}{c}14 \\
(21.5)\end{array}$ & $\begin{array}{c}44 \\
(67.7)\end{array}$ & $5(7.7)$ & 2.66 \\
\hline 5 & $\begin{array}{l}\text { Digital reading emerges positive experience; will often } \\
\text { learn and do assignment using digital media }\end{array}$ & $0(0)$ & $6(9.2)$ & $\begin{array}{c}51 \\
(78.5)\end{array}$ & $8(12.3)$ & 3.03 \\
& & 10 & 65 & 166 & 19 & T: 260 \\
\hline$\sum f$ & & $(3.85)$ & $(25)$ & $(63.85)$ & $(7.3)$ & M: 2.75 \\
\hline$\sum \%$ & & & & &
\end{tabular}

The participants' motivation and interest are positive but very high in level. It may indicate that although they were interested in reading digital texts, they still use printed texts. This is clarified by three of the interviewees.

"Yes, I am interested in reading digital texts. I read more digital than printed texts because digital texts are more convenient and easy to access. I can read them anywhere only by using a smartphone. But reading printed texts is also important." (Interviewee C)

"Although I still read printed texts, digital texts are more interesting for they are easy to access. They are also paperless. Using them, we keep our nature". (Interviewee D)

"I only read books or texts that are interesting to me. For me, digital texts are easier to search for many texts that I want to read. So, I am more motivated to read digital texts". (Interviewee $\mathrm{H}$ )

\section{Digital Text Efficacy}

Table 2 shows that students' belief digital texts efficacy, though they also admitted printed text effectiveness for reading comprehension. Around $70 \%$ of them "agreed" and "strongly agreed" that learning with digital texts is effective, facilitate comprehension improvement, and increased learning achievement. This finding indicates that the participants view both digital and printed texts are not very contrastive in terms of effectiveness for reading comprehension and learning achievement. Both of them seem equal in effectiveness. Therefore, the participants tend to perceive digital texts positively not because they are more effective than printed materials but because of the availability of many sources that help them to get information.

I like using digital texts because they facilitate my learning. I can access innumerable journals and texts without spending too much money to get them" (Interviewee A) 
Digital texts are effective to use in learning. They are easy to bring and read anywhere. I can also access them anytime time." (Interviewee $\mathrm{H}$ )

"Concerning effectiveness, I think there is no difference between digital and printed texts. I read both types." (Interviewee J)

Table 2

Digital Texts Reading Effifacy $(N=65)$

\begin{tabular}{|llccccc|}
\hline No & Statements & SD & D & A & SA & M \\
\hline 1 & Believe that learning with digital text is effective. & $2(3.1)$ & $\begin{array}{c}22 \\
(33.8)\end{array}$ & $\begin{array}{c}37 \\
(56.9)\end{array}$ & $4(6.2)$ & 2.66 \\
\hline 2 & Digital reading is easy in improving my comprehension & $2(3.1)$ & $\begin{array}{c}16 \\
(24.6)\end{array}$ & $\begin{array}{c}43 \\
(66.2)\end{array}$ & $4(6.2)$ & 2.75 \\
\hline 3 & Learning through digital media increased achievement & $0(0)$ & $\begin{array}{c}19 \\
(29.2)\end{array}$ & $\begin{array}{c}44 \\
(67.7)\end{array}$ & $2(3.1)$ & 2.74 \\
\hline 4 & I can easily comprehend printed text & $1(1.5)$ & $\begin{array}{c}19 \\
929.1)\end{array}$ & $\begin{array}{c}44 \\
(67.7)\end{array}$ & $1(1.5)$ & 2.69 \\
\hline$\sum f$ & & 5 & 76 & 168 & 11 & T: 260 \\
\hline$\sum \%$ & & $(1.92)$ & $(29,23)$ & $(64,62)$ & $(4,23)$ & M: 2.71 \\
\hline
\end{tabular}

\section{Difficulty}

The data in Table 3 shows that the majority of the participants encounter no significant problem in reading digital texts. Only around a quarter or less of them "agreed" and "strongly agreed" that reading digital texts cause problems. The most significant problem they faced was eye irritation caused by the screen light. Almost one-third (32.3\%) of the participants "agreed" and "strongly agreed" with the negative effects caused by the screen light to their eyes. This finding clarified Vision Source's (2016) statement that smartphones, computers, and tablets screens make our eyes work harder. Unlike e-readers like the Kindle or Nook which display text and images through e-ink that closely mimics the appearance of ink on printed paper, the screens of smartphones, computers, and tablets use tiny pieces called "pixels." Different from e-ink which reduces the tendency to cause eye strain, focusing on pixels makes our eyes work a little harder than if we were reading a traditional book. Technological advancement has indeed improved screen resolution to reduce eye strain. To prevent eye strain, people who read digital texts a lot are suggested to apply the 20/20/20 rule, i.e., taking a 20second break in every 20 minutes reading by looking at something 20 feet away.

The information obtained from the interview clarifies that some students encounter certain computer-related problems in dealing with digital texts. Sometimes they spoil their reading, but most of them can handle the problems.

"When the virus attacks my gadget and I can't access my e-books and other digital files. That is the problem I have ever experienced concerning digital reading." (Interviewee B)

"I need time to adapt to digital reading. I just began reading digital texts after attending this campus. While in senior high school, I used to read printed texts only. Reading e-books and modules from the lecturers for hours strain my eyes. I usually adapt the screen brightness to my need so that I can finish my reading. (Interviewee D). 
I think adapting to every new activity makes us encounter problems. I love reading digital texts, but if I read on the screen too long I feel my eyes irritated. I used to take a some-minutes break, say after reading for 30 minutes. (Interviewee F).

Table 3

Difficulty in Digital Texts Reading (N=65)

\begin{tabular}{|c|c|c|c|c|c|c|}
\hline No & Statements & SD & D & A & SA & $\mathbf{M}$ \\
\hline 1 & $\begin{array}{l}\text { I get problem to get information when reading } \\
\text { through digital media }\end{array}$ & $\begin{array}{c}13 \\
(20.0)\end{array}$ & $\begin{array}{c}48 \\
(73.8)\end{array}$ & $\begin{array}{c}3 \\
(4.6)\end{array}$ & $\begin{array}{c}1 \\
(1.5)\end{array}$ & 1.88 \\
\hline 2 & $\begin{array}{l}\text { Technical disruption from computer decrease my } \\
\text { reading's motivation and comprehension }\end{array}$ & $\begin{array}{c}11 \\
(16.9)\end{array}$ & $\begin{array}{c}42 \\
(64.6)\end{array}$ & $\begin{array}{c}12 \\
(18.5)\end{array}$ & $0(0)$ & 2.02 \\
\hline 3 & $\begin{array}{l}\text { The light of the screen soon hurts my eyes while } \\
\text { reading digital text }\end{array}$ & $\begin{array}{c}21 \\
(32.3)\end{array}$ & $\begin{array}{c}23 \\
(35.4)\end{array}$ & $\begin{array}{c}12 \\
(18.5)\end{array}$ & $9(13.8)$ & 2.14 \\
\hline 4 & $\begin{array}{l}\text { I always have the digital texts printed before } \\
\text { reading it }\end{array}$ & $\begin{array}{c}26 \\
(40.0)\end{array}$ & $\begin{array}{c}27 \\
(41.6)\end{array}$ & $\begin{array}{c}6 \\
(9.2)\end{array}$ & $\begin{array}{c}6 \\
(9.2)\end{array}$ & 1.88 \\
\hline$\sum f$ & & 71 & 140 & 33 & 16 & $\mathrm{~T}: 260$ \\
\hline$\sum \%$ & & $(27.3)$ & $(53.8)$ & $(12.7)$ & $(6.2)$ & M: 1.98 \\
\hline
\end{tabular}

\section{Preference for Reading Digital or Print Texts}

Table 4 shows that the majority of the respondents preferred to read digital than printed texts. More than $80 \%$ of them "agreed" and "strongly agreed" that they were more often read digital than printed texts, loved searching the internet for relevant additional texts to study, and saved required digital texts in their gadget so they could read them anytime and anywhere they wanted to. This finding supports the finding of Carroll, et al (2016) that digital texts were favored than printed texts for general reference books.

\section{Table 4}

Preference for Reading Digital or Print Texts $(N=65)$

\begin{tabular}{|c|c|c|c|c|c|c|}
\hline No & Statements & SD & D & A & SA & M \\
\hline 1 & I more often read digital than printed texts & $\begin{array}{c}4 \\
(6.2)\end{array}$ & $\begin{array}{c}7 \\
(10.8)\end{array}$ & $\begin{array}{c}35 \\
(53.8)\end{array}$ & $\begin{array}{c}19 \\
(29.2)\end{array}$ & 3.06 \\
\hline 2 & $\begin{array}{l}\text { I love searching the internet for relevant additional } \\
\text { texts to study }\end{array}$ & $\begin{array}{c}5 \\
(7.7)\end{array}$ & $\begin{array}{c}8 \\
(12.3)\end{array}$ & $\begin{array}{c}35 \\
(53.8)\end{array}$ & $\begin{array}{c}17 \\
(26.2)\end{array}$ & 2.98 \\
\hline 3 & $\begin{array}{l}\text { I like keeping required digital texts in my gadget so I } \\
\text { can read them anytime and anywhere want to. }\end{array}$ & $\begin{array}{c}4 \\
(6.2)\end{array}$ & $\begin{array}{c}8 \\
(12.3)\end{array}$ & $\begin{array}{c}35 \\
(53.8)\end{array}$ & $\begin{array}{c}18 \\
(27.7)\end{array}$ & 3.03 \\
\hline$\sum f$ & & 13 & 23 & 105 & 54 & $\mathrm{~T}: 195$ \\
\hline $\bar{\sum} \%$ & & $(6.7)$ & $(11.80$ & $(53.8)$ & (27.7) & M: 3.03 \\
\hline
\end{tabular}

The qualitative data obtained from the interview clarify that the participants actually read both digital and printed texts. However, the became more used to read digital texts because many of their lecturers provided them digital texts only, it was easier to search for information in digital texts, digital texts are cheaper, and digital texts can be easily accessed anytime and anywhere. Some of the interviewees stated the followings.

"My three-semester experiences of learning in this study program has made me a lover of digital texts. I know prefer reading digital texts than printed texts because 
the majority of learning materials are provided by the lecturers in digital texts. The additional materials are also offered in the form of site links in the internet." (Interviewee B)

"For now, I more often read and keep digital texts such as e-books and e-journal articles. It's easier to search information I need to finish my assignments in such texts than in printed books." (Interviewee B)

"I read more digital texts than printed texts because most references and texts from my lecturers are digital. Using digital texts also help me find the information to complete my assignment" (Interviewee D)

"I prefer digital texts than printed materials. Digital text enable me to get the information I need just by typing keywords. When I meet unfamiliar words, many dictionaries or thesaurus are ready to consult in the internet. Thus, using digital texts makes learning easier and quick." (Interviewee G)

\section{The Holistic Students' Perception of Reading Digital Texts}

By comparing the responses to the four indicators, the findings indicate that the students' perception of reading digital texts is most positive in terms of preference. More than $80 \%$ of the respondents "agreed" and "strongly agreed" that they preferred reading digital texts than printed texts. The mean score of the responses obtained for this indicator was 3.03. The second most positive perception is given to motivation and interest. The least positive response is for difficulty indicator. Only $18.9 \%$ of the respondents "agreed" and "strongly agreed" that digital texts caused problem to their reading.

Table 6

Students' Perception of Reading Digital Texts

\begin{tabular}{llccccc}
\hline No. & Indicators & SD \% & D \% & A \% & SA \% & M \\
\hline 1 & Motivation and interest in reading digital texts & 3.85 & 25 & 63.85 & 7.3 & 2.75 \\
\hline 2 & Digital texts reading efficacy & 1.92 & 29,23 & 64,62 & 4,23 & 2.71 \\
\hline 3 & Difficulty in digital texts reading & 27.3 & 53.8 & 12.7 & 6.2 & 1.98 \\
\hline 4 & Preference for reading digital or print texts & 6.7 & 11.80 & 53.8 & 27.7 & 3.03 \\
\hline
\end{tabular}

These findings showed that the participants preferred and were interested to use digital texts than printed texts because most of their lecturers used to assign them digital texts and they were savvy generation who were quite skillful to handle digital texts. This confirmed the conclusion drawn by Pardede (2019b) that "in terms of perception, younger users who are technology savvy generation tend to have more positive attitudes toward digital reading," since that generation usually has appropriate experience and awareness of digital texts.

\section{CONCLUSIONS AND RECCOMMENDATIONS}


Based on the findings and discussions above, it can be concluded that the participants in this study had positive perception of reading digital texts in their academic life. They preferred and were interested to use digital texts than printed texts because most of their lecturers used to assign them digital texts and they were savvy generation who were quite skillful to handle digital texts. They were also motivated to read digital texts because of their availability (low cost), convenience, and accessibility.

Since the participants in this study were of a single educational institution, the findings could not be generalized to other populations outside of study program. Future studies are recommended for to involve a larger number of participants from various educational institutions to make it safer to make generalizations. Also, the indicators of the instruments include statements related to the use of digital reading in general. Future researches are recommended to investigate students' perception of using digital texts for learning more specific language learning areas, e.g. language skills, linguistics, and grammar.

\section{References}

Anderson, N. J. 2003. Scrolling, Clicking, and Searching English: Online Reading Strategies in a Second/Foreign Language. The Reading Matrix. 3(3)

Anuradha, K. T., \& Usha, H. S. (2006). Use of e-books in an academic and research environment: A case study from the Indian Institute of Science, Program: Electronic Library and Information Systems, 40(1), 48-62. DOI:10.1108/00330330610646807

Baier, R. J. (2005). Reading comprehension and reading strategies. American Psychological Association.

Baki, A. (2010). E-book usage of graduate students studying educational sciences in Turkey. Turkish Online Journal of Distance Education, 11(1), 198 - 210.

Bailey, T. P. (2006). Electronic book usage at a master's level I university: A longitudinal study. Journal of Academic Librarianship, 32(1), 52-59. DOI:10.1016/j.acalib.2005.10.004

Carroll, A. J., et al., (2016). E-book perceptions and use in STEM and non-STEM Disciplines: A comparative follow-up study. Portal: Libraries academy, 16(1), 131-162. DOI: $10.1353 /$ pla.2016.0002

Coiro, J., (2003). Reading comprehension on the Internet: Expanding our understanding of reading comprehension to encompass new literacies. The Reading Teacher, 56, pp.458-464

Coiro, J., \& Dobler, E. (2007). Exploring the online reading comprehension strategies used by sixth-grade skilled readers to search for and locate information on the Internet. Reading Research Quarterly, 42(2), 214-257.

Doering, T., Pereira, L. \& Kuechler, L. (2012). The use of e-textbooks in higher education: A case study. ELeader Berlin

Elley, W. B. (1991). Acquiring literacy in a second language: The effect of book-based programs. Language Learning, 41(3), 375-411.

Eradem, Aliye. (2014). A Research on reading habits of university students: (Sample of Ankara University and Erciyes University). Procedia - Social and Behavioral Sciences, 174(12), 3983-3990., DOI: https://doi.org/10.1016/j.sbspro.2015. 01.1145.

Grabe, W. (2009). Reading in second language: Moving from theory to practice. Cambridge University Press, 
Gilbert, J. (2017). A Study of ESL students' perceptions of their digital Reading. The Reading Matrix: An International Online Journal, Vol. 17.

Jamali, H.R. Nicholas, D. \& Rowlands, I. (2009). Results from the JISC National EBook Observatory. Aslib Proceeding: New Information Perspectives. 61 (1), 3347.

Johnson, L., Levine, A., Smith, R., \& Stone, S. (2010). The 2010 Horizon Report. Retreived from ERIC: http://eric.ed.gov/?id=ED510220

Kazu, I., Kazu, H., \& Ozdemir, O. (2005). The effects of mastery learning model on the success of students who attended "usage of basic information technologies" course. Educational Technology and Society, 8, 233-243.

Khan, A., et al. (2016). E-books usage by agricultural, engineering and social science students in selected universities of Pakistan. The Electronic Library, 34(6), 958973. DOI: 10.1108/EL-08-2015-0163

Kiriakova, M., Okamoto, K. S., Zubarev, M., \& Gross, G. (2010). Aiming at a moving target: Pilot testing ebook readers in an urban academic library. Computers in Libraries, 30, 20-24

Kocak, O, et al (2016). Investigating the status of tablet computers and e-books use of open education faculty students: A case study. Int. J. Distance Edu. Technol., 14(2), 49-63. DOI: 10.4018/IJDET.2016040104

Kumbhar, R. (2018). Trends in E-book Research. DESIDOC Journal of Library \& Information Technology, 38(3), pp. 162-169, DOI: 10.14429/djlit.38.3.12382

Levine-Clark, M. (2006). Electronic book usage: A survey at the University of Denver. Libraries and the Academy, 6, 285-299. DOI:10.1353/pla.2006.0041

Lewellen, R., et al. (2016). EBL ebook use compared to the use of equivalent print books and other resources. Performance Measurement Metrics, 17(2), 150-164. DOI: 10.1108/PMM-04-2016-0013

Liaw, S.-S. \& H.-M. Huang (2014). Investigating learner attitudes toward e-books as learning tools: based on the activity theory approach. Interactive Learning Environments, 1-19.

Mizrachi, D. (2014). Online or print: which do students prefer? In Serap Kurbanoglu, Sonja Spiranec, Esther Grassian, Diane Mizrachi \& Ralph Catts (Eds.), Information Literacy, Lifelong Learning and Digital Citizenship in the 21st Century. Second European Conference, ECIL 2014, Dubrovnik, Kroatia, October 20-23, 2014, Proceedings, (pp. 733-742). Heidelberg, Germany: Springer. (Communications in Computer and Information Science, CCIS, 492).

Nelson, M. R. (2008). E-books in higher education: nearing the end of the era of hype? Educause Review, 43(2), 40.

Nicholas, A. \& Lewis, J. (2008). Millennial attitudes toward books and e-books. Retrieved from http://papers.ssrn.com/sol3/papers.cfm?abstract_id=2684872

Pardede, P. (2019a). Mixed Methods Research Designs in EFL In: PROCEEDING English Education Department Collegiate Forum (EED CF) 2015-2018. Jakarta: UKI Press. pp. 230-243. Retrieved May 2019 from http://repository.uki.ac.id/view/creators/Pardede=3A Parlindungan=3A=3A.html

Pardede, P. (2019b). Print vs. digital reading comprehension in EFL: A Literature Review. Journal of English Teaching, 5(2), 77-90. DOI: http://dx.doi.org/10.33541/jet.v5i2.1059

Pardede, P. (2019c). Pre-service EFL teachers' perception of blended learning. Journal of English Teaching, 5(1), 1-14. DOI: http://dx.doi.org/10.33541/jet.v5i1.955 
Pardede, P. (2017). Factors attributed to contradictory research findings in print reading vs. digital reading effectiveness: A Literature Review. Paper presented at UKI's English Education Department Bimonthly Collegiate Forum held on Friday, October 6, 2017

Pattuelli, M. C., \& Rabina, D. (2010). Forms, effects, function: LIS students' attitudes towards portable e-book readers. Aslib Proceedings, 62(3), 228-244. doi: 10.1108/00012531011046880

Schramm, M. (2015). Survey: 78\% of students prefer digital course material. Retrieved January 2019 from https://www.usatoday.com/story/college/2015/07/30/survey78-of-students-prefer-digital-course-material/37405111/

Science, J. (2018). How is reading digitally different than reading print? STEM Learning.

Shelburne, W. (2009). E-book usage in an academic library: User attitudes and behaviors. Library Collections, Acquisitions, \& Technical Services, 33(2/3), 5972. doi:10.1016/j.lcats.2009.04.002

Shirattudin, N., Hassan, S., \& Landoni, M. (2003). A usability study for promoting eContent in higher education. Educational Technology \& Society, 6(4), 112-124.

Shumaker D. (2017). Print Books vs. Ebooks: Who's Up, Who's Down and where are we Headed?. Information Today. Retrieved February 2019 from http://newsbreaks.infotoday.com/NewsBreaks/Print-Books-vs-Ebooks-Whos-UpWhos-Down-and-Where-Are-WeHeaded-118868.asp

Smith, P. (2009). Student perceptions of electronic textbooks. Issues in Information Systems. Vol. 2.

Vassiliou, M. \& Rowley, J. (2008). Progressing the definition of "e-book". Library Hi Tech, 26(3), 355-368.

Vision Source. (2016). Print vs. Digital: Which Is Better For Your Eyesight? Retrieved March 2019 from https://visionsource.com/blog/print-vs-digital-which-is-betterfor-your-eyesight/

$\mathrm{Wu}$, T. T., \& Chen, A. C. (2018). Combining e-books with mind mapping in a reciprocal teaching strategy for a classical Chinese course. Computers \& Education, 116, 64-80. 